\title{
Matched Unrelated Donor (MUD): An Emerging need for Peripheral Blood Stem Cell Transplant
}

\author{
Vikash C Mishra* \\ Chimera Translational Research Fraternity Pvt. Ltd, India
}

Submission: November 15, 2018; Published: November 28, 2018

*Corresponding author: Vikash C Mishra, Chimera Translational Research Fraternity Pvt. Ltd, New Delhi, India

Keywords: Thalassemia; Blood transfusion; Hematopoietic; Donors; Oxygen

Abbreviations: WBC: White Blood Cells; RBC: Red Blood Cells; BRD: Blood Related Disorders; ALL: Acute Lymphoblastic Leukemia; AML: Acute Myelogenous Leukemia; CLL: Chronic Lymphocytic Leukemia; CML: Chronic Myelogenous Leukemia; HL: Hodgkin Lymphoma; NHL: Non-Hodgkin Lymphoma (NHL); SAA: Severe Aplastic Anemia; SDD: Sickle Cell Disease

\section{Background}

Blood is a vital component of human body which is involved in many functions most importantly supplying oxygen along with essential nutrients to various parts of body to maintain the growth. It also acts as excretory mediator as it helps in elimination of waste by product. Blood is made up of four components commonly known as Red Blood Cells (RBC), plasma, platelets and White Blood Cells (WBC). Each component plays its important role to maintain the regulations in the human body. In case if there is any malfunctioning in either of these components, this leads to blood disorders. Common types of Blood Related Disorders (BRD) are Acute Lymphoblastic Leukemia (ALL), Acute Myelogenous Leukemia (AML), Chronic Lymphocytic Leukemia (CLL), Chronic Myelogenous Leukemia (CML), Hodgkin Lymphoma (HL), Non-Hodgkin Lymphoma (NHL), Severe Aplastic Anemia (SAA), Sickle cell disease (SCD) and Thalassemia.

\section{Treatment Management available for the Patient}

\section{Chemotherapy}

The most conventional method of treatment. Drugs that are often used to treat leukemia, lymphoma etc. In addition, it can also use for patient conditioning required for prior to stem cell transplant.

\section{Radiation therapy}

Treatment that uses a form of energy to destroy cancerous cells and may also is used for patient conditioning required before stem cell transplant.

\section{Blood transfusions}

Red blood cells (RBC) or platelets given to patients who have too few of these blood cells and required regular blood transfusion like in case of Thalassemia Major.

\section{Peripheral Blood Stem Cell Transplant (PBSCT)}

An approved therapy for blood cancers and other BRDs. Peripheral Blood stem cell (PBSC) can be defined as seeds which are capable of producing the new blood components. They are mainly synthesized in bone marrow. Basic requirements for PBSCT are availability of a donor, who can donate his or her stem cells to the needy patients. Donor can be related (knows as "Matched Related Donor", MRD) and unrelated (known as "Matched Unrelated Donor", MUD). The chances of finding suitable MRD is only 25\% (siblings and other family members), but for remaining $75 \%$ patients there is need of MUD who is suitable for donation which will be you, me and any healthy individual above 18 years of age. Realizing the importance of MUD, many countries across the globe have initiated to recruit people voluntarily who give their informed consent to donate their hematopoietic stem cells (HSC) in order to help patients suffering from BRDs and blood cancer. There are 75 stem cell registries worldwide with more than 32 million registered. Unfortunately, in India, a country with population over 120 million however, representing less than 0.25 million donors.

\section{Eligibility to become a MUD for PBSCT}

A healthy individual above 18 years of age who has given informed consent for donation and is Human Leukocyte Antigen 
(HLA) matched. In simple words, immunologically compatible with the patients. HLA is responsible for regulation of an individual immune system and it has power to discriminate between self and non-self.

\section{Voluntary Stem Cell Donor registry (VSCDR) and its function}

There are 75 stem registries across globe. Voluntary matched unrelated stem cell donor recruitment drives are conducted to spread awareness among the people and motivate them to register as a MUD. Once the donors have given their consent, sample is taken, and high-resolution HLA typing has done, and result is uploaded in World Marrow Donor Association (WMDA), an international repository of worldwide donors.

\section{Steps of MUD Recruitment}

Attend counseling session by registry counselor
a) Understand the procedure
b) Sign the consent form
c) Give the sample
d) HLA typing of all the registered donor
e) Data updation in WMDA

\section{Search engine for MUD availability}

VSCDR have HLA data of donors who are willing to donate their hematopoietic stem cells to BRD patients. There are 4 stem cell registries in India (Genebandhu, Datri, MDRI and TTK) working on building up large donor data pool. The search for patient is done by matching the HLA data of patients and donor and if they get matched then proceeds for transplant.

\section{Current MUD scenario for Indian patient}

India is the second most populated country in the world with population over 120 million and has been subjected to different waves of immigration. With 22 official languages, India has mixture of various ethnicities, cultures, languages, marriages within communities which have resulted in unique gene pool. The chances of finding donor for a patient within his own community are more. But unfortunately, Indian donor represents less than 0.25 million out of 32 million donors resulting in very a smaller number of chances to finding a donor.

\section{Conclusion}

Thus, to conclude, there is a need of enhanced awareness among people about Peripheral Blood Stem cell (PBSC) donation to build a larger pool of MUD and educate them about how this process will benefit their own society and specially the patients of India by making the transplant affordable and accessible. If the MUD pool increases the chance of finding MUD within India also increases which not only reduces the cost of the PBSCT but also making treatment more accessible to patient across India. To increase the number of MUD an initiative must be taken to educate people on PBSC donation and spreading awareness, the VSCDR to have a dedicated staff and counselor in order to explain and educate about the concept in simple language. If people get aware that they can save someone's life by donating their stem cell.
Your next submission with Juniper Publishers will reach you the below assets

- Quality Editorial service

- Swift Peer Review

- Reprints availability

- E-prints Service

- Manuscript Podcast for convenient understanding

- Global attainment for your research

- Manuscript accessibility in different formats

( Pdf, E-pub, Full Text, Audio)

- Unceasing customer service

Track the below URL for one-step submission

https://juniperpublishers.com/online-submission.php 